\title{
Gaseous emission comparison of a compression-ignition engine fueled with different biodiesels
}

\author{
Ş. Altun • C. Öner
}

Received: 20 May 2011/Revised: 28 December 2011/Accepted: 22 March 2012/Published online: 14 December 2012 (C) CEERS, IAU 2012

\begin{abstract}
In this study, it was performed a comparison of the performance and emissions of two methyl ester fuels: one obtained from animal fat and the other from crude canola oil, in a compression-ignition engine against diesel fuel. The experimental results compared with diesel fuel showed that significant reductions could be obtained by biodiesel derived from animal fat in carbon monoxide and oxides of nitrogen emissions. Carbon dioxide emissions showed a trend of decreasing with the biodiesel fuels. An increase in brake specific fuel consumption was observed for different biodiesel fuels when compared with diesel fuel. It was concluded that animal tallow methyl ester performed better than canola oil methyl ester, whereas slightly higher brake torque is observed with canola oil methyl ester.
\end{abstract}

Keywords Air pollution - Diesel · Performance

\section{Introduction}

The use of oxygenated fuels such as alcohols, vegetable oils and biodiesel is a promising approach to reduce diesel engine emissions which is one of the largest contributors to environmental pollution problems worldwide (Lloyd and

\footnotetext{
Ş. Altun $(\bowtie)$

Teknik Eğitim Fakültesi Makine Eğitimi Bölümü, Batman Üniversitesi, Kültür Mahallesi T.P.A.O Bulvarı, 72100 Batman, Turkey

e-mail: saltun72@yahoo.com

C. Öner

Otomotiv Mühendisliği Bölümü, Teknoloji Fakültesi, Frrat Üniversitesi, 23119 Elazig, Turkey
}

Cackette 2001; Di et al. 2009; Song et al. 2008). However, using alcohol fuels in diesel engines have some limitations, because it has lower viscosity and lubricity, reduced ignitability and cetane number, low energy content, higher volatility and lower miscibility (Lapuerta et al. 2008). Biodiesel is a renewable diesel fuel derived from vegetable oils or animal fats via the chemical process of transesterification, and it is one of the most attractive solutions as an alternative diesel fuel or fuel additive. Biodiesel offers several fuel advantages over petroleum diesel, including improved lubricity, lower toxicity, biodegradability, and no net contribution to the greenhouse effect because it is made from renewable resources (Wyatt et al. 2005). Biodiesel can be blended in any proportion with petroleum diesel fuel, and blended biodiesel, mainly in blends of $20 \%$ (B20) or less, can be used in most conventional diesel engines with little or no modification (Jung et al. 2006). Besides, the wear of various vital parts gets reduced because of additional lubricant properties of biodiesel (Agarwal 2007). For exhaust emissions, in general, many researchers consider that biodiesel, derived from various sources, causes a decrease of unburned hydrocarbon (HC), $\mathrm{CO}$ and particulate matter (PM) emissions (Çanakçı 2007; Keskin et al. 2008; Aksoy 2011). However, most of the studies show that biodiesel causes an increase in $\mathrm{NO}_{\mathrm{x}}$ emissions, while only a few papers have reported no changes or reduction in $\mathrm{NO}_{\mathrm{x}}$ emissions (Lapuerta et al. 2009; Öner and Altun 2009). This may be attributed to differences in fatty acid composition of biodiesel fuels. Because fuel properties of biodiesel are affected by its fatty acid contents, they may cause difference in the characteristics of emissions (Özsezen et al. 2008a), since biodiesel fuels obtained from different feedstocks have different physical and chemical properties (Lin and Li 2009; McCormick et al. 2001; Altun 2011a; Refaat 2009). For 
instance, Wu et al. (2009) studied the emissions of five biodiesel fuel with different sources including cottonseed, soybean, rapeseed, palm oil and waste cooking oil methyl ester. It was concluded in study that biodiesels reduce emissions, and reduction largely depends on the fuel. In another study, it was found that unsaturated biodiesels show slightly increased $\mathrm{NO}_{\mathrm{x}}$ and $\mathrm{PM}$ emissions compared to their saturated biodiesels (Knothe et al. 2006).

In this study, the performance and exhaust emission characteristics of a direct injection diesel engine were experimentally investigated using different biodiesel fuels. Biodiesel fuels used in this study were produced from crude canola oil and inedible animal tallow by transesterification using methanol and an alkaline catalyst. The experimental results were compared with petroleum diesel fuel and with each other.

\section{Materials and methods}

Biodiesel production and fuel properties

Fatty acid methyl ester of crude canola oil and inedible animal tallow were prepared by base-catalyzed transesterification with methanol in the presence of $\mathrm{NaOH}$ as catalyst. Inedible animal tallow was provided from a local slaughterhouse (Katiboğlu meat production corp., located in Elazığ, Turkey). These inedible fats can be obtained from abdominal parts of slaughtered cattle and sheep during meat preparation process, and they are collected in a caldron and then melted. Afterwards, they are filtered and marketed for soap production. Methanol (purity 99.7\%) was used for transesterification and purchased from a commercial supplier. Sodium hydroxide with purity of $98 \%$ was used as the alkali catalysts in the reaction. Animal tallow methyl ester (ATME) was prepared by basecatalyzed transesterification of inedible animal tallow with methyl alcohol in the presence of $\mathrm{NaOH}$ as catalyst. Biodiesel was produced using a methyl alcohol to tallow ratio of $6: 1$ with sodium hydroxide $(\mathrm{NaOH})$ as catalyst $(0.5 \%$ of tallow by weight). The mixture of alcohol and catalyst was added to the melted tallow. Then the mixture of oilalcohol-catalyst was stirred rigorously throughout $3 \mathrm{~h}$ at $60{ }^{\circ} \mathrm{C}$. The mixture was then allowed to cool in room temperature. After the methyl ester and glycerol layers were separated, and the ester was purified by washing with distilled water and drying to room temperature.

Crude canola oil (non-food grade) was purchased from commercial oil supplier, located in Diyarbakır, Turkey. Crude canola oil was transesterified to convert the canola oil methyl ester (COME) using methyl alcohol and a base catalyst $(\mathrm{NaOH})$. The canola oil is preheated in reaction flask to remove the moisture. Sodium methoxide was prepared by dissolving sodium hydroxide in methanol. An amount of methyl alcohol equal to $20 \%$ of prepared oil was mixed with $0.4 \% \mathrm{NaOH}$, volumetrically. Sodium methoxide added to canola oil at $60{ }^{\circ} \mathrm{C}$ and the reaction carried out stirring at reaction temperature of $60{ }^{\circ} \mathrm{C}$ for $2 \mathrm{~h}$. After glycerol separation, methyl ester was washed with warm water to remove impurities.

The fatty acid distribution of canola oil methyl ester and inedible tallow methyl ester was obtained from Moser B.R (2008) and Ali et al. (1995), and presented in Table 1. As seen in Table 1, predominant fatty acid of animal tallow methyl ester is oleic acid (48.18\%), palmitic acid $(23.76 \%)$ is the next most abundant FA, followed by stearic acid $(13.79 \%)$. The fatty acid composition of animal tallow methyl ester are different from canola oil methyl ester in that oleic acid $(64.3 \%)$ is the predominant FA, followed by linoleic $(20.2 \%)$ and linolenic (7.6\%) acids. According to Table 1, the animal tallow methyl ester's saturated fatty acid amount is $39.34 \%$, while canola oil methyl ester is $7.7 \%$ saturated. This can be significant when considering the benefits of a fuel with high cetane number on diesel engine combustion process. Because more saturated biodiesels have higher cetane numbers than less saturated esters.

The biodiesels and diesel fuel were characterized by determining their viscosity, density, heating value and cetane number in the Fuel Analysis Laboratory of Department of Automotive Engineering in Cukurova University, Adana, Turkey. The properties of neat biodiesel fuels and petroleum diesel fuel are presented in Table 2. In order to determine the properties of the diesel fuel, the biodiesels and their blends, the following test instruments were used. K40001/K40091 Automatic Kinematic Viscosity System from Koehler Instrument Company, DA-130 Portable Density/Specific Gravity Meter (Resonant Frequency Method) from Kyoto Electronics (KEM),

Table 1 Fatty acids (wt \%) of methyl esters from animal tallow and canola oil

\begin{tabular}{llll}
\hline Fatty acid & Carbon chain & Canola oil & Animal tallow \\
\hline Myristic & C14:0 & - & 1.35 \\
Palmitic & C16:0 & 4.6 & 23.76 \\
Stearic & C18:0 & 2.1 & 13.79 \\
Arachidic & C20:0 & 0.7 & - \\
Behenic & C22:0 & 0.3 & - \\
Palmitoleic & C16:1 & 0.2 & 2.6 \\
Oleic & C18:1 & 64.3 & 48.18 \\
Linoleic & C18:2 & 20.2 & 9.88 \\
Linolenic & C18:3 & 7.6 & - \\
Saturated fatty acids & & 7.7 & 39.34 \\
Unsaturated fatty acids & & 92.3 & 60.66 \\
\hline
\end{tabular}


Automated Flash Point Tester model APM-7 (PenskyMartens Closed Cup) from Tanaka Scientific Limited and IKA WERKE C2000 Basic Calorimeter system, ZX-440 Cetane Number Analyzer (NIR spectrometry) from Zeltex Inc. It can be seen in Table 2 that differences between the fuels mainly lies in two of the properties: cetane number and viscosity. Also, it should be pointed out that more saturated biodiesels have worse cold flow properties, as widely reported in literature (Lapuerta et al. 2009; McCormick et al. 2001).

\section{Engine tests}

The performance and exhaust emission tests were conducted on a four-cylinder, four-stroke, naturally aspired, water-cooled and direct injection Mitsubishi canter diesel engine. The basic specifications of test engine are given in Table 3. A schematic diagram of the experimental setup, comprises a hydraulic dynamometer, a fuel tank, gravimetric fuel consumption meter, data acquisition system and an exhaust emissions analysis system, is shown in Fig. 1. A hydraulic dynamometer (Netfren brand) is connected to test engine to provide brake load, which is available for measuring and adjusting the speed and torque of the engine. A magnetic pick-up sensor was used to measure the speed of the engine which was fixed over the gear on the dynamometer shaft. The load on the dynamometer measures using a load cell. Fuel consumption was measured with a gravimetric fuel consumption meter. Several temperature sensors installed in the engine were used to control the engine operation and measure of the temperatures. The lubricating oil and coolant temperatures were measured by thermocouples. The exhaust gas temperature

Table 2 The fuel properties of diesel fuel and biodiesel fuels

\begin{tabular}{lllll}
\hline Properties & Unit & Diesel fuel & COME & ATME \\
\hline Density (at $15{ }^{\circ} \mathrm{C}$ ) & $\mathrm{kg} / \mathrm{m}^{3}$ & 833 & 881 & 865 \\
Viscosity $\left(\right.$ at $40^{\circ} \mathrm{C}$ ) & $\mathrm{mm}^{2} / \mathrm{s}$ & 2.95 & 4.89 & 5.628 \\
Heating value & $\mathrm{MJ} / \mathrm{kg}$ & 45.65 & 40.2 & 39.8 \\
Cetane number & $\mathrm{CN}$ & 54.63 & 55.56 & 59.27 \\
\hline
\end{tabular}

Table 3 The basic specifications of test engine

\begin{tabular}{ll}
\hline Engine brand & Mitsubishi canter diesel \\
\hline Engine type & Naturally aspired, water-cooled \\
Operating principle & Four stroke, direct injection \\
Number of cylinder & Inline four cylinders \\
Bore $\times$ Stroke & $104 \times 115 \mathrm{~mm}$ \\
Fuel injection pump & Mechanically controlled in-line type \\
Maximum torque & $243 \mathrm{Nm}$ at $1,600 \mathrm{rpm}$ \\
\hline
\end{tabular}

was measured by K-type thermocouple. The exhaust emissions were measured by an exhaust analyzer (Testo 350-XL), which was calibrated before each test. Parameters of the instrument used for the measurement of the exhaust gases are given in Table 4.

Petroleum diesel fuel was provided from a commercial supplier (Petrol Office Firm, located in Adana, Turkey). The engine was started with petroleum diesel fuel and warmed up for a sufficient time to reach steady state operational conditions for each fuel. The warm up period ends when the cooling water temperature is stabilized. The results evaluated here were obtained at full load conditions with the engine speeds between 1,000 and 2,000 rpm with intervals of $250 \mathrm{rpm}$. For every fuel change, the fuel tank and lines were cleaned. Before running the engine to a new fuel, it was allowed to run for some time to consume the remaining fuel from the previous experiment. The data were taken after the engine was run with the new fuel for enough time (25-30 min).

\section{Results and discussion}

This section discusses the effect of biodiesel fuels produced from different feedstocks on the diesel engine performance and exhaust emissions. Experimental results were plotted against the engine speed and presented on Figs. 2, 3, 4 and 5.

As shown in Fig. 2, when the engine was fueled with different biodiesels, the brake torque was reduced compared with $\mathrm{DF}$. The maximum brake torque $(236.5 \mathrm{Nm})$ at 1,500 rpm was obtained with DF, followed by COME $(209.6 \mathrm{Nm})$ and ATME $(207.7 \mathrm{Nm})$. On average over the speed range at full load condition, the brake torques of COME and ATME decreased by 11.6 and $13 \%$, respectively, compared with those of DF. Figure 3 illustrates a comparison of the brake specific fuel consumption (BSFC) with engine speed at full load conditions using different biodiesel fuels and diesel fuel. Figure 3 shows that BSFC decreases with the increase in engine speed and becomes minimum (at maximum torque region), and then increases again. At the engine speed of 1,500 rpm, the BSFCs run by COME are increased by $8.7 \%$. For ATME fuel, the same trend can be seen from the Fig. 3, the increase of BSFC was $6.4 \%$. On average, BSFCs for COME and ATME are higher by 10.45 and $8.6 \%$ than that of DF, respectively. The heating value of biodiesel fuels from different feedstocks that are about $12 \%$ less than for diesel fuel can be given as a reason for an increase in BSFC. Because of the lower energy content of the biodiesels, the BSFCs increased when compared to DF. Since the heating value of biodiesel fuels per unit mass was lower than DF, the fuel consumption had to be higher to maintain maximum brake 
Fig. 1 Schematic diagram of the experimental setup

To Atmosphere

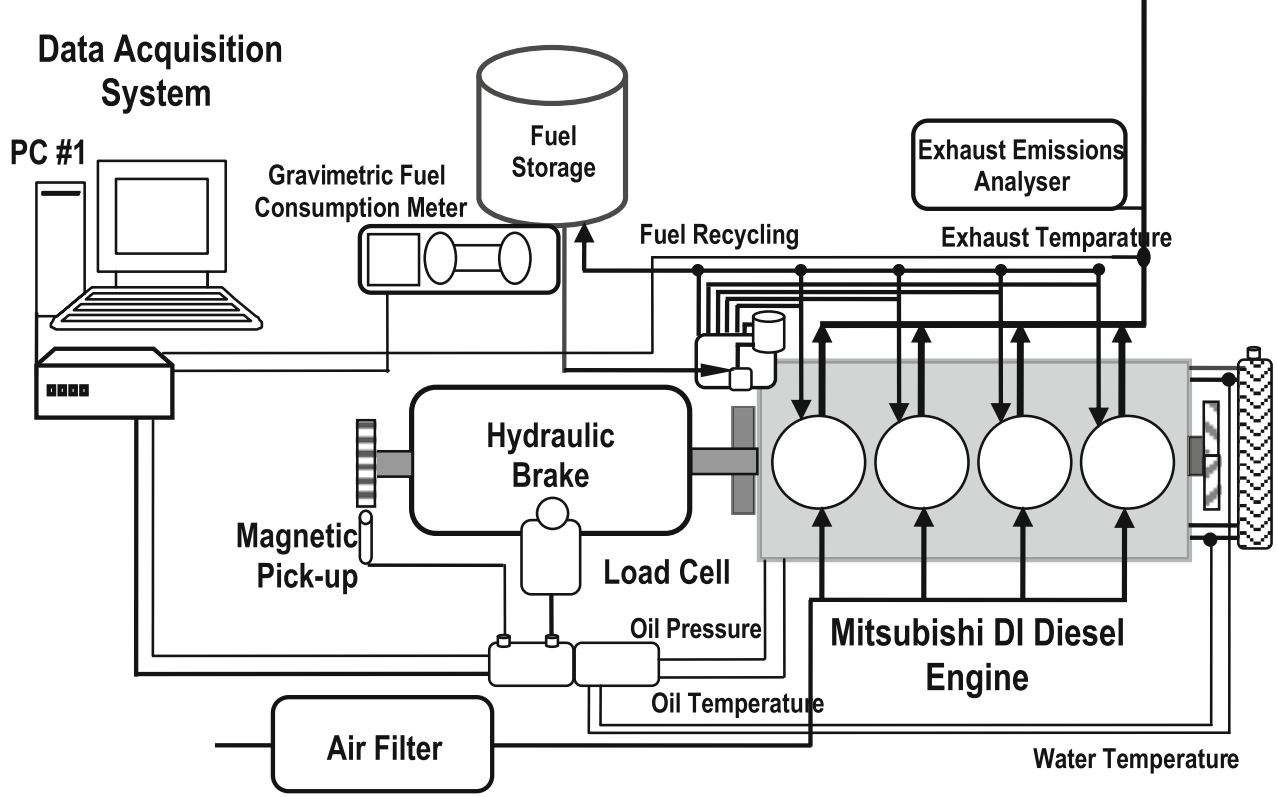

Table 4 Parameters of exhaust gas analyze

\begin{tabular}{llllll}
\hline Measured components & & & & & \\
\hline Gas analyzer & $\mathrm{CO}$ & $\mathrm{CO}_{2}$ & $\mathrm{O}_{2}$ & $\mathrm{NO}$ \\
\hline Testo $350 \mathrm{XL}$ & & & & & \\
Limits & $0 . .+10000 \mathrm{ppm}$ & $0 . .25 \% \mathrm{vol}$ & $0 . .+25 \% \mathrm{vol}$ & $0 . .+500 \mathrm{ppm}$ & $0 . .+3000 \mathrm{ppm}$ \\
Accuracy & $\pm 5 \%$ & $\pm 0.3 \%$ & $\pm 0.8 \%$ & $\pm 5 \%$ & $\pm 5 \%$ \\
\hline
\end{tabular}

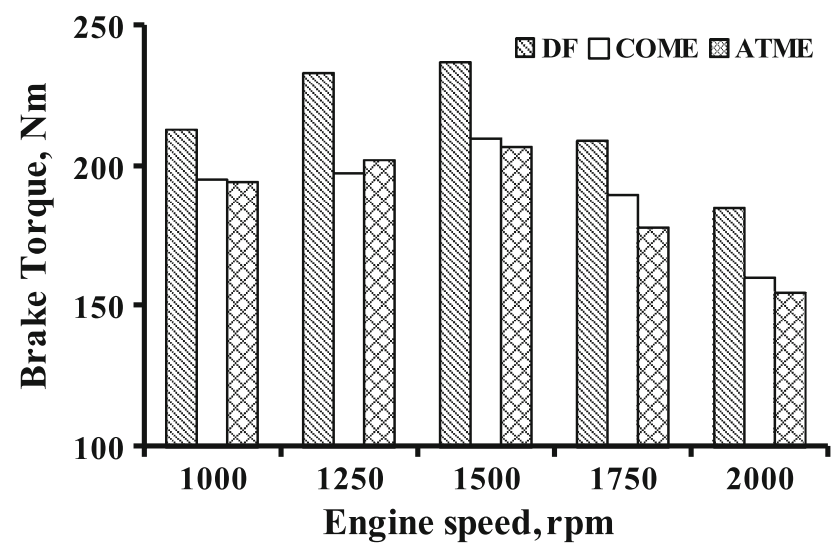

Fig. 2 The variation in the brake torque for different biodiesel fuels

torque at the full load condition. Increased specific fuel consumption when biodiesel fuels are used is reported by Kaplan et al. (2006) and Altun (2011b). However, a comparison between COME and ATME shows that although they have almost the same heating value, COME shows slightly higher BSFC than ATME. The high density of COME can be given as a reason, as shown in Table 2, and

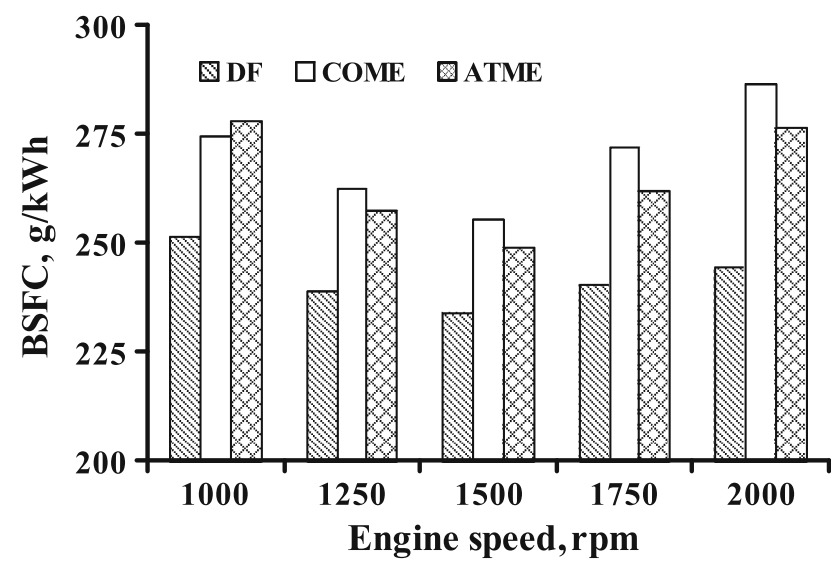

Fig. 3 The variation in BSFC for different biodiesel fuels

hence more mass of COME fuel is injected in the same volume at the same injection pressure.

Figure 4 shows the $\mathrm{CO}$ emissions using different biodiesels and petroleum diesel fuel. As shown in the Fig. 4, different biodiesels and petroleum diesel fuel have similar $\mathrm{CO}$ emission trend in relation to the engine speed. This shows that the combustion behaviors of fuels tested and in 


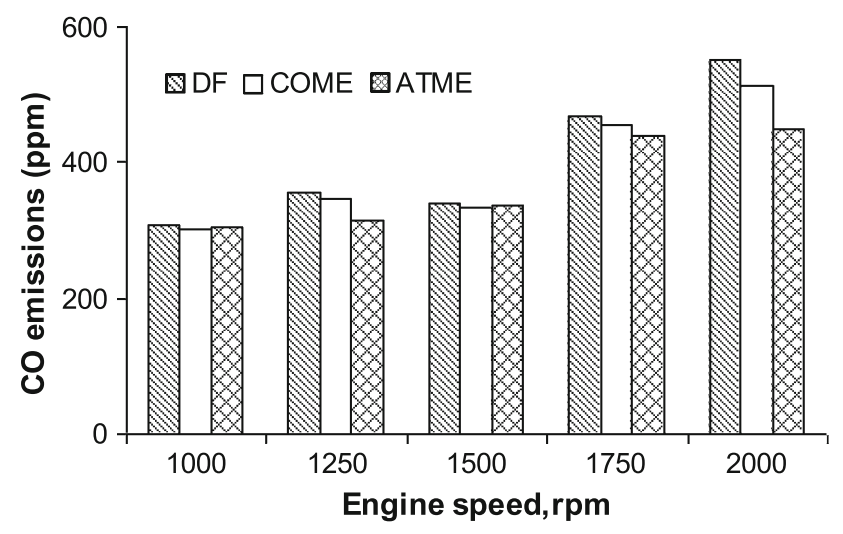

Fig. 4 CO emissions for different biodiesel fuels and diesel fuel against engine speed

this study were similar to each other. The $\mathrm{CO}$ emissions are low when the engine runs at the low engine speeds, and $\mathrm{CO}$ emissions are high at higher engine speeds. On average, $\mathrm{CO}$ emissions of all engine speeds for ATME and COME compared to those of DF decreased. Biodiesel fuels from different sources contain molecular oxygen, the additional oxygen content in the fuel enhances the complete combustion of the fuel, thus reducing $\mathrm{CO}$ emissions. In present study, lowest $\mathrm{CO}$ emissions were obtained by neat animal fat biodiesel, although biodiesel fuels have almost the same oxygen content. This may be due to shorter ignition delay of neat animal fat biodiesel, owing to its higher cetane number. As a matter fact, Özsezen et al. (2008b) concluded that shorter ignition delay of biodiesel when compared to diesel fuel caused the extension of the combustion or oxidation timing, and thus, $\mathrm{CO}$ emissions are reduced by the combustion of biodiesel. Kim and Choi (2010) also reported that $\mathrm{CO}$ emissions were reduced due to the decrease in the ignition delay by the cetane number improver.

Carbon dioxide $\left(\mathrm{CO}_{2}\right)$ emissions are primary greenhouse gases, and it is produced when the fuels are complete burned. Figure 5 shows a comparison of the $\mathrm{CO}_{2}$ emission values obtained for the fuels tested at the full load over the speed range. It can be seen from Fig. 5 that the different biodiesels produced the lower $\mathrm{CO}_{2}$ emissions than those of diesel fuel. Among the biodiesel fuels, ATME produced higher $\mathrm{CO}_{2}$ emission than COME. ATME has also produced lower $\mathrm{CO}$ emission than COME, as shown in Fig. 4. It is understood that the complete combustion is improved when using ATME compared with COME.

Experimental studies have shown that there is generally an increase in $\mathrm{NO}_{\mathrm{x}}$ emissions when using biodiesel in diesel engines. The increase in $\mathrm{NO}_{\mathrm{x}}$ emissions by biodiesel has been mostly attributed to oxygen content and advanced injection timing by researchers (Kegl 2007; Tat et al. 2007; Zhang and Boehman 2007). Figure 6 shows the results of

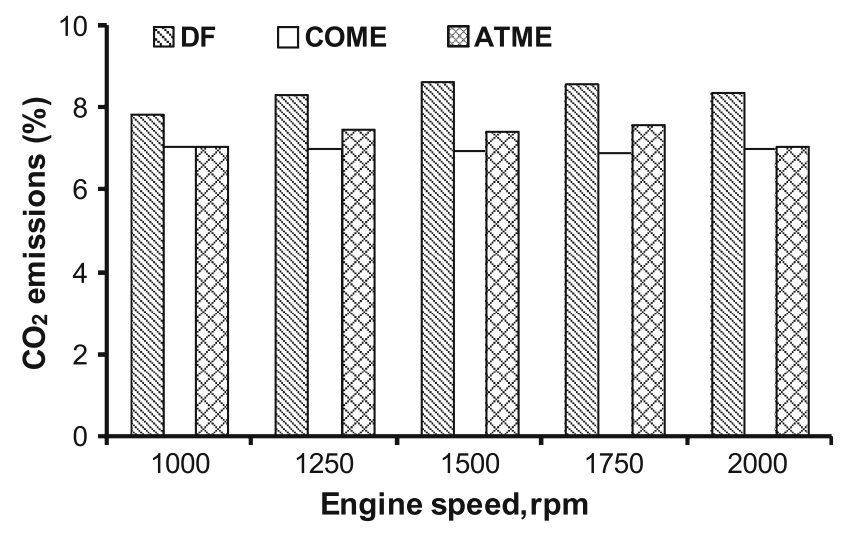

Fig. $5 \mathrm{CO}_{2}$ emissions for different biodiesel fuels and diesel fuel against engine speed

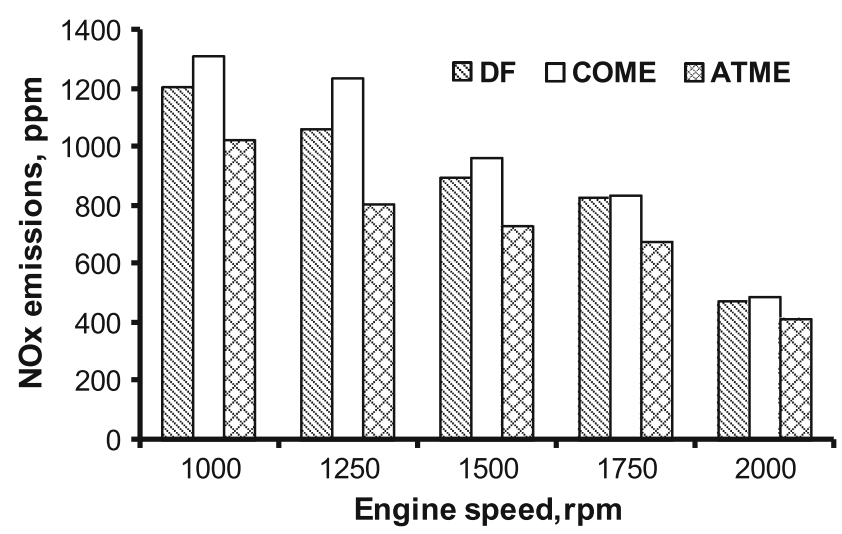

Fig. $6 \mathrm{NO}_{\mathrm{x}}$ emissions for different biodiesel fuels and diesel fuel against engine speed

$\mathrm{NO}_{\mathrm{x}}$ emissions from the engine tests fueled with three different fuels (DF, ATME and COME). From Fig. 6, it can be seen that the $\mathrm{NO}_{\mathrm{x}}$ emissions of biodiesel from animal fat are mostly lower than those of pure diesel and canola oil biodiesel. The $\mathrm{NO}_{\mathrm{x}}$ emissions are higher for COME by $7.3 \%$ and lower for ATME by $18.3 \%$ as compared to diesel fuel, on average. At the speed of $1500 \mathrm{rpm}, \mathrm{NO}_{\mathrm{x}}$ emissions are $18.65 \%$ less for ATME; $6.96 \%$ more for COME. The presence of more oxygen in the combustion chamber leads to the more complete combustion, and hence the higher combustion temperature which causes the increasing $\mathrm{NO}_{\mathrm{x}}$ formation. On the other hand, higher viscosity and bulk modulus cause advanced injection timing. This causes an increase of pressure and temperature in the cylinder, which leads to higher $\mathrm{NO}_{\mathrm{x}}$ emissions (Kegl 2007).

$\mathrm{NO}_{\mathrm{x}}$-decreasing trend when using more saturated biodiesel fuels has been recently reported in other works (Lapuerta et al. 2009; Öner and Altun 2009), as a result of the higher cetane number of the fuel. The fuel having the higher cetane number exhibits shorter ignition delay period 
and a less amount of fuel burned in the premixed mode, and hence lower $\mathrm{NO}_{\mathrm{x}}$ emissions. This is commonly used to explain the less $\mathrm{NO}_{\mathrm{x}}$ emissions when using more saturated biodiesels (McCormick et al. 2001; Myo 2008).

\section{Conclusion}

The experimental results in this study can be summarized as follows: The brake torque is decreased with the different biodiesels when compared with diesel fuel. The brake specific fuel consumptions of engine are slightly higher when the engine is fueled with the two biodiesels compared with that of diesel fuel. $\mathrm{CO}$ emissions were lower with the biodiesels when compared to diesel fuel emissions. Besides, animal fat biodiesel produced lowest $\mathrm{CO}$ emission among the fuels tested. $\mathrm{CO}_{2}$ emissions showed a trend of decreasing with the biodiesel fuels. $\mathrm{NO}_{\mathrm{x}}$ emissions for ATME decreased with respect to those measured for petroleum diesel fuel, and in the case of COME, $\mathrm{NO}_{\mathrm{x}}$ emissions remained slightly above those of petroleum diesel fuel.

Acknowledgments The authors wish to acknowledge all who supported and assisted in conduction of this study.

\section{References}

Agarwal AK (2007) Biofuels (alcohols and biodiesel) applications as fuels for internal combustion engines. Prog Energy Combust Sci 33(3):233-310

Aksoy F (2011) The effect of opium poppy oil diesel fuel mixture on engine performance and emissions. Int $\mathrm{J}$ Environ Sci Tech $8(1): 57-62$

Ali Y, Hanna MA, Cuppett SL (1995) Fuel properties of tallow and soybean oil esters. JAOCS 72:1557-1564

Altun S (2011a) Fuel properties of biodiesels produced from different feedstocks. Energy Edu Sci Technol Part A 26(2):165-174

Altun Ş (2011b) Performance and exhaust emissions of a DI diesel engine fueled with waste cooking oil and inedible animal tallow methyl esters. Turkish J Eng Env Sci 35:107-114

Çanakçı M (2007) Combustion characteristics of a turbocharged DI compression ignition engine fueled with petroleum diesel fuels and biodiesel. Bioresource Technol 98:1167-1175

Di Y, Cheung CS, Huang Z (2009) Comparison of the effect of biodiesel-diesel and ethanol-diesel on the particulate emissions of a direct injection diesel engine. Aerosol Sci Tech 43:455-465

Jung H, Kittelson DB, Zachariah M (2006) Characteristics of SME biodiesel-fueled diesel particle emissions and the kinetics of oxidation. Environ Sci Technol 40:4949-4955

Kaplan C, Arslan R, Sürmen A (2006) Performance characteristics of sunflower methyl esters as biodiesel. Energ Source A 28:751755
Kegl B (2007) $\mathrm{NO}_{\mathrm{x}}$ and particulate matter (PM) emissions reduction potential by biodiesel usage. Energ Fuel 21:3310-3316

Keskin A, Gürü M, Altıparmak D, Aydın K (2008) Using of cotton oil soapstock biodiesel-diesel fuel blends as an alternative diesel fuel. Renew Energ 33:553-557

Kim H, Choi B (2010) The effect of biodiesel and bioethanol blended diesel fuel on nanoparticles and exhaust emissions from CRDI diesel engine. Renew Energy 35:157-163

Knothe G, Sharp CA, Ryan TW (2006) Exhaust emissions of biodiesel, petrodiesel, neat methyl ester and alkanes in a new technology engine. Energ Fuel 20:403-408

Lapuerta M, Armas O, Herreros JM (2008) Emissions from a dieselbioethanol blend in an automotive diesel engine. Fuel 87:25-31

Lapuerta M, Rodriguez-Fernandez J, Oliva F, Canoira L (2009) Biodiesel from low-grade animal fats: diesel engine performance and emissions. Energ Fuel 23:121-129

Lin C-Y, Li R-J (2009) Fuel properties of biodiesel produced from the crude fish oil from the soapstock of marine fish. Fuel Process Technol 90:130-136

Lloyd AC, Cackette TA (2001) Diesel engines: environmental impact and control. J Air Waste Manage Assoc 51:809-847

McCormick RL et al (2001) Impact of biodiesel source material and chemical structure on emissions of criteria pollutants from a heavy-duty engine. Environ Sci Technol 35(9):1742-1747

Moser BR (2008) Influence of blending canola, palm, soybean, and sunflower oil methyl esters on fuel properties of Biodiesel. Energ Fuel 22:4301-4306

Myo T (2008) The effect of fatty acid composition on the combustion characteristics of biodiesel, Ph.D thesis, Graduate School of Science and Engineering Kagoshima University, p 171

Öner C, Altun Ş (2009) Biodiesel production from inedible animal tallow and an experimental investigation of its use as alternative fuel in a direct injection diesel engine. Appl Energy 86:2114-2120

Özsezen AN, Çanakçı M, Sayın C (2008a) Effects of biodiesel from used frying palm oil on the performance, injection, and combustion characteristics of an indirect injection diesel engine. Energ Fuel 22:1297-1305

Özsezen AN, Çanakçı M, Sayın C (2008b) Effects of biodiesel from used frying palm oil on the exhaust emissions of an indirect injection (IDI). Diesel Engine Energ Fuel 22:2796-2804

Refaat AA (2009) Correlation between the chemical structure of biodiesel and its physical properties. Int J Environ Sci Tech 6(4):677-694

Song R, Liu J, Wang L, Liu S (2008) Performance and emissions of a diesel engine fuelled with methanol. Energ Fuel 22:2883-2888

Tat ME, Van Gerpen JH, Wang PS (2007) Fuel property effects on injection timing, ignition Timing, and oxides of nitrogen emissions from biodiesel-fueled engines. Transactions of the ASABE 50(4):1123-1128

Wu F, Wang J, Chen W, Shuai S (2009) A study on emission performance of a diesel engine fueled with five typical methyl ester biodiesels. Atmos Environ 43:1481-1485

Wyatt VT, Hess MA, Dunn RO, Foglia TA, Haas MJ, Marmer WN (2005) Fuel properties and nitrogen oxide emission levels of biodiesel produced from animal fats. J American Oil Chem Soc 82(8):585-591

Zhang Y, Boehman AL (2007) Impact of biodiesel on $\mathrm{NO}_{\mathrm{x}}$ emissions in a common rail direct injection diesel engine. Energ Fuel 21:2003-2012 